\title{
De positie van de aandeelhouder bij een gedwongen omzetting van schuld in aandelenkapitaal buiten insolventie
}

\author{
Mr. G.J.L. Bergervoet*
}

\begin{abstract}
1 Introductie
Het omzetten van schuld in aandelenkapitaal, of een debt for equity swap, kan voor een onderneming een manier zijn om in financieel moeilijke tijden het hoofd boven water te houden. ${ }^{1}$ Zeker wanneer een onderneming te kampen heeft met een hoge schuldenlast, maar nog wel goede onderliggende financiele resultaten produceert, kan een debt for equity swap een aantrekkelijke wijze zijn om de vermogenspositie te verbeteren. Door de omzetting verdwijnen immers schuld en bijbehorende rentelasten, terwijl het uitgeven van aandelen zonder wezenlijke kosten kan geschieden. ${ }^{2}$ Voor de zittende aandeelhouder betekent het uitgeven van nieuwe aandelen echter wel dat zijn positie mogelijk verwatert of misschien effectief verdwijnt. Een aandeelhouder die doordrongen is van het feit dat de hoge schuldenlast ervoor zorgt dat er voor hem weinig tot geen aandeelhouderswaarde meer is, zal wellicht geneigd zijn om mee te werken aan de omzetting, om zodoende ook zelf nog wat waarde te behouden. Indien de aandeelhouder echter overtuigd is dat de onderneming waarvan hij aandeelhouder is ook zonder een omzetting van schuld in aandelenkapitaal gezond kan voortbestaan, of om andere redenen zijn aandelenbelang niet wil zien verwateren, kan hij besluiten niet mee te werken aan de omzetting. Aangezien zonder aandeelhoudersbesluit een uitgifte van aandelen in beginsel niet zal slagen (vergelijk art. 2:96 en 2:206 van het Burgerlijk Wetboek, $\mathrm{BW}),{ }^{3}$ kan daarmee een patstelling ontstaan tussen de schuldeisers van de onderneming en de aandeelhouder, die niet eenvoudig kan worden doorbroken.
\end{abstract}

In deze bijdrage ga ik in op de mogelijkheden die het Nederlandse recht buiten insolventie biedt voor schuldeisers van een onderneming om de zittende andeelhouder te dwingen

\footnotetext{
Mr. G.J.L. Bergervoet is advocaat bij Clifford Chance te Amsterdam en is daarnaast als fellow verbonden aan het Onderzoekcentrum voor Onderneming \& Recht aan de Radboud Universiteit Nijmegen.

1. De Angelsaksische term debt for equity swap kan op een ruimere wijze worden geïnterpreteerd en toegepast, maar blijft voor de doeleinden van deze bijdrage beperkt tot een omzetting van schuld in aandelenkapitaal.

2. Het uitgeven van nieuwe aandelen is slechts een van meerdere technieken voor de verwezenlijking van de omzetting van schuld in aandelenkapitaal, zie N.W.A. Tollenaar, Debt for equity swaps, in: N.E.D. Faber e.a. (red.), De bewindvoerder, een octopus, Deventer: Kluwer 2008, p. 67.

3. Tenzij bijv. bij de statuten een ander orgaan is aangewezen.
}

medewerking te verlenen aan een omzetting van schuld in aandelenkapitaal. ${ }^{4}$ Daarbij ga ik ervan uit dat de betreffende onderneming in financiële nood verkeert en er daarom snel gehandeld moet worden. Vanuit een vermogensrechtelijk perspectief is hier een interessante kwestie aan de orde. Wanneer mag een aandeelhouder zich niet langer verschuilen achter zijn vennootschapsrechtelijke bevoegdheden en zijn belang om verwatering tegen te gaan, omwille van het behoud van het vermogensrechtelijk belang dat inmiddels (grotendeels) rust bij de schuldeisers van de vennootschap? En in hoeverre zou een dergelijke gedwongen debt for equity swap naar Nederlands recht kunnen worden gerealiseerd, zonder dat daarbij bijvoorbeeld in strijd wordt gehandeld met het recht van een aandeelhouder op het ongestoord genot van zijn eigendom uit art. 1 van het Eerste Protocol bij het Europees Verdrag tot bescherming van de rechten van de mens en de fundamentele vrijheden (EP EVRM)?

De in de praktijk beproefde methode van het starten van een enquêteprocedure bij de Ondernemingskamer van het Gerechtshof Amsterdam (OK) komt in deze bijdrage ten eerste aan de orde. De OK heeft al in een groot aantal zaken bijgedragen aan de spoedige totstandkoming van een gedwongen omzetting van schuld in aandelenkapitaal, bijvoorbeeld door de rechten van de aandeelhouder tijdelijk toe te kennen aan het bestuur van de onderneming. Aan de hand van de lessen die kunnen worden getrokken uit deze rechtspraak van de $\mathrm{OK}$, zal worden bekeken of een succesvolle gedwongen debt for equity swap ook denkbaar is buiten de context van een enquêteprocedure, te weten in een procedure bij de voorzieningenrechter. Ten slotte zal aandacht worden besteed aan de mogelijkheden die het Nederlandse recht in de toekomst wellicht gaat bieden voor een gedwongen omzetting van schuld in aandelenkapitaal, meer specifiek als het wetsvoorstel Wet continuiteit ondernemingen II (WCO II) wordt gepromoveerd tot wet.

4. De gedwongen omzetting van schuld in aandelen op basis van de SRMverordening en de Richtlijn herstel en afwikkeling van banken en beleggingsondernemingen (Richtlijn 2014/59/EU) - zoals binnenkort geïmplementeerd in de $\mathrm{Wft}$ - valt buiten de reikwijdte van deze bijdrage. 


\section{Debt for equity swaps bij de OK}

\subsection{De kracht van de onmiddellijke voorziening}

Het starten van een enquêteprocedure bij de OK kan een nuttig middel zijn om snel een debt for equity swap te bewerkstelligen. Waar de enquêteprocedure in de kern is bedoeld om een onderzoek naar het beleid en de gang van zaken binnen de onderneming te faciliteren en daarbij mogelijk wanbeleid vast te stellen en weg te nemen, is het in veel gevallen de verzoeker van de procedure echter niet om dit onderzoek te doen. De enquêteprocedure wordt daarbij oneigenlijk gebruikt om bijvoorbeeld een oplopend conflict binnen de onderneming snel te beslechten of een dreigend faillissement te voorkomen. ${ }^{5} \mathrm{De}$ mogelijkheid die de OK heeft om aan deze verzoeken tegemoet te komen is de zogenaamde onmiddellijke voorziening die zij kan treffen op grond van art. 2:349a lid 2 BW. De kracht van de onmiddellijke voorzieningen van de OK is (1) dat zij snel kunnen worden getroffen en (2) dat de OK een grote mate van vrijheid toekomt bij het bepalen van de inhoud van de voorziening.

Wat betreft het snelle handelen van de OK kan het volgende worden opgemerkt. De OK kan in elke fase van de procedure een onmiddellijke voorziening treffen. Dit betekent dat zelfs wanneer er nog geen onderzoek is gelast, zij over kan gaan tot het treffen van een onmiddellijke voorziening, mits er naar het voorlopig oordeel van de OK gegronde redenen zijn om te twijfelen aan een juist beleid of juiste gang van zaken binnen de onderneming (art. 2:349a lid 3 BW). De OK kan snel handelen als 'de toestand van de onderneming' daarom vraagt. Opgemerkt zij overigens dat de OK niet ambtshalve over kan gaan tot het treffen van een voorziening. Een vereiste voor het treffen van een voorziening door de $\mathrm{OK}$ is dat daarom is verzocht. $^{6}$

Qua inhoud van de onmiddellijke voorziening komt aan de OK een zeer grote mate van vrijheid toe. Zo herhaalde de Hoge Raad recent nog in zijn beschikking van 11 juli 2014, NJ 2014/389 (Novero) het oordeel dat de OK:

'de vrijheid heeft zodanige onmiddellijke voorzieningen te treffen als zij in verband met de toestand van de rechtspersoon noodzakelijk acht, ook indien daarbij tijdelijk inbreuk wordt gemaakt op de geldende rechtsverhoudingen binnen de rechtspersoon. Aan het treffen van zodanige voorzieningen hoeft niet zonder meer in de weg te staan dat deze kunnen leiden tot onomkeerbare gevolgen, mits de voorziening naar haar aard een voorlopige is en bij het treffen van een zodanige voorziening voldoende rekening is gehouden met, en een billijke afweging heeft plaatsgevonden van, de belangen van de betrokken partijen. Dit brengt mee dat de ondernemingskamer iedere voorziening

5. Vgl. C.D.J. Bulten \& C.J.H. Jansen, Rechterlijk activisme: waar liggen de grenzen van rechtsvorming door de Ondernemingskamer?, Ondernemingsrecht 2015/20, p. 125 .

6. P.G.F.A. Geerts, Enkele formele aspecten van het enquêterecht (diss. Groningen), Deventer: Kluwer 2004, p. 251. van voorlopige aard mag treffen mits met het oog op de gevolgen ervan een billijke afweging van de belangen van partijen heeft plaatsgevonden en de noodzaak van deze voorziening voldoende is gebleken. Het laatste is met name ook het geval als naar het oordeel van de ondernemingskamer een minder ingrijpende maatregel niet effectief zou zijn.'7 (cursivering GJLB)

Voeg aan het bovenstaande nog toe dat de voorziening van de OK niet alleen tijdelijk inbreuk mag maken op de geldende rechtsverhoudingen binnen de rechtspersoon door af te wijken van wat is bepaald in de statuten, maar dat tevens tijdelijk kan worden afgeweken van dwingend recht, ${ }^{8}$ en het moge duidelijk zijn dat de onmiddellijke voorziening een krachtig middel is om snel resultaat te verkrijgen.

\subsection{Onder welke omstandigheden honoreert de OK een debt for equity swap?}

De OK heeft reeds in verschillende (spraakmakende) zaken onmiddellijke voorzieningen getroffen die erop waren gericht om te voorkomen dat een dwarsliggende aandeelhouder de continuïteit van de onderneming in gevaar kon brengen. Zo heeft de OK onder meer in de Skygate-beschikking voorzieningen getroffen die erop zagen dat het bestuur van een vennootschap kon stemmen in de algemene vergadering om zodoende een converteerbare lening uit te kunnen schrijven, ${ }^{9}$ heeft zij in de Decidewise-beschikking het bestuur tijdelijk gemachtigd - in strijd met de statuten en de geldende aandeelhoudersovereenkomst - om onder goedkeuring van de raad van commissarissen tot emissie van aandelen over te gaan, ${ }^{10}$ en in de Inter Access-beschikking zelfs het bestuur van een vennootschap bevoegd gemaakt tot het uitgeven van aandelen met uitsluiting van het voorkeursrecht van de overige aandeelhouders. ${ }^{11}$ Kortom, de OK heeft in het verleden contractuele, statutaire en zelfs dwingendrechtelijke bepalingen tijdelijk opzijgezet om zodoende een emissie van aandelen mogelijk te maken. Maar welke omstandigheden moeten zich aandienen voordat de $\mathrm{OK}$ tot het treffen van deze voorzieningen overgaat? Met andere woorden, wat zijn de voorwaarden waaronder het beroep van een aandeelhouder op zijn recht om uitgifte of verwatering tegen te houden niet langer toegestaan is?

De bestendige lijn van rechtspraak van de OK laat zien dat een drietal voorwaarden moet zijn vervuld om het treffen van een onmiddellijke voorziening die gericht is op emissie te rechtvaardigen. ${ }^{12}$ In de eerste plaats moet de onderneming gecon-

7. HR 11 juli 2014, NJ 2014/389 m.nt. PvS (Novero).

8. Zie nr. 2.11 concl. A-G Timmerman bij HR 14 september 2007, NJ 2007/611 m.nt. Maeijer, JOR 2007/238 m.nt. Bartman (Versatel II) en Asser/Maeijer, Van Solinge \& Nieuwe Weme 2-II* 2009/772.

9. Hof Amsterdam (OK) 27 januari 2000, JOR 2000/74 m.nt. Josephus Jitta (Skygate).

10. Hof Amsterdam (OK) 15 november 2001, JOR 2002/6 m.nt. Josephus Jitta (Decidewise)

11. Hof Amsterdam (OK) 31 december 2009, JOR 2010/60 m.nt. Doorman (Inter Access)

12. Zie Doorman, noot bij Hof Amsterdam (OK) 31 december 2009, JOR 2010/60 (Inter Access). 
fronteerd zijn met een financieel probleem dat het voortbestaan daarvan bedreigt. Daarnaast moet sprake zijn van een besluitvormingsproces binnen de onderneming dat in een impasse verkeert. Ten slotte moet de oplossing voor het financiële probleem dat de continuïteit van de onderneming bedreigt, bij afwezigheid van alternatieve oplossingen, zijn gelegen in het emitteren van aandelen. Indien aan deze drie voorwaarden is voldaan, is de OK bereid gebleken om over te gaan tot het treffen van onmiddellijke voorzieningen die hebben bijgedragen tot het kunnen voltooien van het emissieproces bij gebreke van goedkeuring van de betreffende zittende (meerderheids)aandeelhouder. ${ }^{13}$

$\mathrm{Nu}$ heeft zich tot op heden nog geen zuivere casus aangediend die in deze bijdrage centraal staat, namelijk schuldeisers (niet tevens zijnde aandeelhouders) die bij de OK verzoeken om een gedwongen debt for equity swap en waarbij dat verzoek door middel van een onmiddellijke voorziening door de OK wordt gehonoreerd. De OK heeft zich echter in een zodanige mate proactief opgesteld wanneer het voortbestaan van een onderneming op het spel staat, dat er vanuit mijn optiek - behalve eventuele ontvankelijkheidsperikelen (zie par. 2.4 hierna) niets aan in de weg zou staan om aan te nemen dat de $\mathrm{OK}$ bereid is om een onmiddellijke voorziening te treffen die een gedwongen omzetting van schuld in aandelen bewerkstelligt als de toestand van de onderneming daarom vraagt.

\subsection{Kritiek uit literatuur: art. 1 EP EVRM en procedurele waarborgen}

Het kordate, misschien zelfs activistische optreden van de $\mathrm{OK}$ heeft lof, maar ook kritiek opgeleverd van verschillende auteurs. Zo zijn er zorgen geuit naar aanleiding van de Inter Access-beschikking over het mogelijk strijdige karakter van die beschikking met art. 1 EP EVRM. De verwatering, die als gevolg van de onmiddellijke voorziening optrad, zou neerkomen op een inbreuk op het ongestoorde recht op eigendom van de aandeelhouder en daarom in strijd kunnen zijn met art. 1 EP EVRM. Daarnaast menen sommige critici dat het optreden van de $\mathrm{OK}$ in het kader van de gedwongen emissie en/of verwatering van aandelen plaatsvindt binnen een procedure die slechts weinig procedurele waarborgen kent en daarom beter zou kunnen geschieden bij de voorzieningenrechter.

De eventuele strijdigheid met art. 1 EP EVRM is uitgebreid aan de orde gekomen in de literatuur, mede naar aanleiding van de Inter Access-beschikking van de OK en de daaropvol-

13. Hof Amsterdam (OK) 27 januari 2000, JOR 2000/74 m.nt. Josephus Jitta (Skygate), Hof Amsterdam (OK) 15 november 2001, JOR 2002/6 m.nt. Josephus Jitta (Decidewise), Hof Amsterdam (OK) 29 november 2002, JOR 2003/8 m.nt. Josephus Jitta (Alcas) en Hof Amsterdam (OK) 31 december 2009, JOR 2010/60 m.nt. Doorman (Inter Access). gende beschikking van de Hoge Raad in die zaak. ${ }^{14}$ Art. 1 EP EVRM biedt de eigenaar bescherming tegen inbreuken op zijn eigendom, waarbij aan de eigenaar in beginsel een ongestoord genot van zijn eigendom toekomt. ${ }^{15}$ Een inbreuk op het eigendomsrecht is slechts toegestaan indien, zo blijkt uit vaste rechtspraak van het Europees Hof voor de Rechten van de Mens (EHRM), de inbreuk (1) is voorzien bij wet, (2) het algemeen belang dient en (3) proportioneel is. ${ }^{16} \mathrm{Nu}$ zal de inbreuk die wordt veroorzaakt door een beschikking van de OK op grond van haar vaste criteria - mits juist toegepast en gemotiveerd - steeds wel kunnen voldoen aan het dienen van het algemeen belang en tevens proportioneel zijn. De oplossing die wordt gezocht door de OK ziet immers op het behouden van de continuïteit van de onderneming en daarmee samenhangende economische belangen, waartoe ook behoort de met de onderneming verbonden werkgelegenheid. Ook zal de OK alleen een onmiddellijke voorziening treffen die een gedwongen emissie bewerkstelligt indien dat de enige oplossing is om de financiële continuiteit van de onderneming te garanderen, waarmee in mijn optiek wordt voldaan aan het vereiste dat de inbreuk op het eigendomsrecht proportioneel moet zijn.

Voornamelijk ten aanzien van de voorzienbaarheid bij wet van het ingrijpen van de $\mathrm{OK}$ in de Inter Access-beschikking zijn vraagtekens te plaatsen. Sommige schrijvers hebben zich terughoudend opgesteld bij het baseren van de voorzienbaarheid bij wet op de bevoegdheid van de OK tot het treffen van onmiddellijke voorzieningen uit art. 2:349a BW. ${ }^{17}$ In navolging van A-G Timmerman hebben recent meerdere auteurs de lijn gevolgd dat art. 2:349a BW wel reeds voldoende is om de voorzienbaarheid bij wet in de zin van de rechtspraak van het EHRM aan te kunnen nemen. ${ }^{18}$ Ik denk dat art. 2:349a BW op zichzelf moeilijk als een voldoende voorzienbare basis kan gelden om een inbreuk op het eigendomsrecht te rechtvaardigen, zonder de wijze te kennen waarop de OK deze bepaling

14. Zie o.m. concl. A-G Timmerman bij HR 25 februari 2011, JOR 2011/115 (Inter Access), nr. 3.20 e.v., A.J.P. Schild, De betekenis van art. 1 Eerste Protocol voor het ondernemingsrecht, NJCM-Bulletin 2007 , afl. 5, p. 603-624, B.F. Assink, Op de rand van de afgrond bloeien de mooiste bloemen, Ondernemingsrecht 2010/7, p. 327-332, M.L. Lennarts, Majority Shareholders Sidelined by the Dutch Business Court: The Inter Access Case in Light of Article 1 Protocol 1 EHCR, European Company Law 2010, afl. 5, p. 210-216, R. Niesink, Voorlopige voorzieningen in enquêteprocedures en de bescherming van het recht op eigendom, V\&O 2010, afl. 5, p. 97-100, F. Eikelboom, Een toetsingskader voor het treffen van voorzieningen in het enquêterecht: art. 1 van het Eerste Protocol bij het EVRM, Ondernemingsrecht 2009/15, p. 606-611, A. Doorman, JOR 2011/115 (Inter Access), A.J.P. Schild, De invloed van het EVRM op het ondernemingsrecht (diss. Leiden), Deventer: Kluwer 2012, hoofdstuk 4 en F. Veenstra, Overleven dankzij het enquêterecht, TvI 2015/7.

15. Het eigendomsrecht wordt daarbij autonoom geinterpreteerd en is dus niet beperkt tot het begrip eigendom uit het BW, maar wordt geacht mede vermogensrechten te omvatten.

16. Zie Schild 2012, p. 126 e.v. voor een uitvoerige bespreking en een overzicht van rechtspraak.

17. Zie o.m. Niesink 2010, p. 99-100 en Lennarts 2010, p. 215-216.

18. A-G Timmerman bij HR 25 februari 2011, JOR 2011/115 (Inter Access), nr. 3.20 e.v., Schild 2012, p. 158-160 en F. Veenstra 2015, p. 47. 
toepast en - overeenkomstig het mandaat dat zij van de Hoge Raad daartoe krijgt - mag gebruiken om op te treden bij impasses in de besluitvorming van ondernemingen. Er bestaat echter inmiddels een bestendige lijn van jurisprudentie waarbij grotendeels is uitgekristalliseerd hoe en onder welke omstandigheden de OK voorzieningen kan treffen die een debt for equity swap mogelijk maken. Nu ook de wijze waarop een artikel in de jurisprudentie wordt toepast als voorzienbaarheid bij wet in de zin van de rechtspraak van het EHRM oplevert, ${ }^{19}$ zou ik menen dat een debt for equity swap op basis van een onmiddellijke voorziening van de $\mathrm{OK}$ a priori geen problemen hoeft op te leveren met art. 1 EP EVRM.

Andere kritiek die is geuit aangaande de procedure bij de OK is dat zij als enige feitelijke instantie oordeelt en daarbij verregaande maatregelen treft, terwijl bij het treffen van zulke maatregelen eigenlijk beter een toets door twee feitelijke instanties zou passen. ${ }^{20} \mathrm{Bij}$ de herziening van het enquêterecht heeft de wetgever - mijns inziens terecht - echter gemeend dat ondernemingen en hun stakeholders vooral behoefte hebben aan een spoedige oplossing van het geschil, omdat het voortduren van een procedure veel tijd en kosten met zich brengt. ${ }^{21}$ Een toets door twee feitelijke instanties zou de snelheid van de procedure verminderen, wat onwenselijk is. De OK is dan wellicht alleenheerser als het aankomt op het waarderen van de feiten, maar wat betreft de toepassing van het enquêterecht als zodanig wordt zij nauwlettend in de gaten gehouden door de Hoge Raad. Op die manier kan een proces snel plaatsvinden, maar wordt het niettemin aan een bepaalde mate van toezicht onderworpen.

\subsection{Praktisch bezwaar: enquêteprocedure niet altijd toegankelijk voor schuldeisers}

Het werd net al aangestipt dat er zich tot op heden nog geen casus bij de OK heeft aangediend waarin schuldeisers van een onderneming de zittende aandeelhouders dwingen om mee te werken aan een omzetting van schuld in aandelen. Deels zal dit te maken hebben met het feit dat de - baanbrekende Inter Access-beschikking relatief recent is gewezen. Wellicht is er nog geen casus geweest waarbij de gang naar de OK de enig overgebleven optie was voor de schuldeisers om een gedwongen debt for equity swap te bewerkstelligen. Er is echter nog een reden te bedenken waarom de casus van een gedwongen debt for equity swap die door schuldeisers wordt geëntameerd nog niet bij de $\mathrm{OK}$ is gebracht: deze reden ziet op de toegang van partijen tot een enquêteprocedure.

Sinds de wijziging van het enquêterecht in 2013 is de enquêteprocedure qua toegankelijkheid aanmerkelijk gewijzigd. Zo is er vanaf 1 januari 2013 voor aandeelhouders van beursgeno-

19. EHRM 9 november 1999, appl. nr. 26449/95 (Spacek/Republiek Tsjechië), par. 54 en 57.

20. H.J. de Kluiver, Noodzaakfinanciering en de rol van de rechter, in: G. van Solinge e.a., De financiering van de onderneming (Serie vanwege het Van der Heijden Instituut, deel 88), Deventer: Kluwer 2006, p. 31-49; SERadvies 2008/01 (Evenwichtig ondernemingsbestuur), p. 52.

21. MvT, Kamerstukken II 2010/11, 32887, 3, p. 22-23. teerde ondernemingen een hogere drempel (te weten het houden van $1 \%$ van het geplaatst kapitaal of een minimaal belang van EUR 20 miljoen) ingesteld om toegelaten te worden tot een enquêteprocedure, terwijl per diezelfde datum de toegankelijkheid voor de rechtspersoon zelf en de curator juist van een wettelijke basis is voorzien. ${ }^{22}$ Zowel onder het oude regime als naar geldend recht hebben schuldeisers van de onderneming in beginsel geen toegang tot de enquêteprocedure. Dat zal slechts anders zijn indien de betreffende schuldeisers tevens aandeelhouder van de onderneming zijn, of wanneer zij krachtens overeenkomst met de onderneming of krachtens de statuten zijn gerechtigd tot het instellen van een verzoek tot een enquêteprocedure (art. 2:346 lid 1 sub e BW). Hoewel het contractueel verlenen van (voorwaardelijke) enquêtebevoegdheid in financieringsdocumentatie in toenemende mate wordt gebruikt als alternatief voor bijvoorbeeld het kunnen uitoefenen van de stemrechten in een vennootschap, ${ }^{23}$ zijn er ook veel financieringstransacties waarbij dit recht niet wordt toegekend aan de schuldeisers. Voor de schuldeisers aan wie geen contractuele of statutaire bevoegdheid tot het entameren van een enquêteprocedure is toegekend, rest in een dergelijk geval nog de mogelijkheid om door middel van het bestuur van de vennootschap de enquêteprocedure te starten. Zonder medewerking van de rechtspersoon zelf in de vorm van het bestuur is de mogelijkheid van een gedwongen debt for equity swap bij de $\mathrm{OK}$ voor schuldeisers dus niet aanwezig in dat scenario.

\section{Procedure bij de voorzieningenrechter}

\subsection{De voorzieningenrechter als reëel alternatief?}

De enquêteprocedure heeft een grote vlucht genomen in de afgelopen jaren en begint zich op een wijze te verhouden tot de civiele procedure die in toenemende mate als een strijd tussen gelijken kan worden aangemerkt als het gaat om geschillenbeslechting ten aanzien van ondernemingen; een wedstrijd tussen de 'oude dame' en de 'efficiënte dienstmaagd', zo is het wel betiteld in de literatuur. ${ }^{24}$ Zeker wat betreft het treffen van voorzieningen over het emitteren van nieuwe aandelen in financieel penibele situaties heeft de $\mathrm{OK}$ als 'efficiënte dienstmaagd' vaker moeten optreden dan de voorzieningenrechter in een civiele procedure. $\mathrm{Nu}$ zal in een situatie waar de financi-

22. Zie over de mogelijkheid voor een curator om een enquêteprocedure te starten, D.J.F.F.M. Duynstee \& E.J.R. Verwey, Het enquêterecht voor de curator, in: De gereedschapskist van de curator, Deventer: Kluwer 2015, p. $75-96$.

23. Vgl. Hof Amsterdam (OK) 29 oktober 2012, JOR 2013/9 m.nt. Spruitenburg (Nijl Holding), Ph.W. Schreurs \& L.H.J.C. Hendriks, Het enquêterecht voor banken en andere verschaffers van vreemd vermogen: een onbetreden maar begaanbaar pad, FIP 2012, p. 44-47 en J.H.M. Willems, Externe vermogensverschaffers en enquêtebevoegdheid: een reactie, FIP 2012, p. 122-125.

24. Vgl. M.W. Josephus Jitta, Enkele gedachten over het formele enquêterecht; is het efficiënt wanneer de dienstmaagd moeder wordt?, in: M.W. Josephus Jitta \& M.R. Mok, Het recht van enquête onderzocht (Preadvies van de Vereeniging 'Handelsrecht'), Alphen aan den Rijn: Kluwer 2004, p. 1-42 en M. Sinnighe Damsté, K.J. Smit \& S. Berendsen, Samenloop van de enquêteprocedure en de civiele procedure: een (wed)strijd tussen de oude dame en de efficiënte dienstmaagd, O\&F 2008, afl. 2, p. $87-107$. 


\section{Maandblad \\ Vermogensrecht}

ele nood hoog oploopt het entameren van een bodemprocedure niet opportuun zijn, simpelweg omdat daarvoor de tijd ontbreekt. Dit bezwaar is echter niet aanwezig bij het starten van een kort geding. ${ }^{25}$ Schuldeisers zullen, anders dan bij een enquêteprocedure bij de $\mathrm{OK}$, in beginsel wel toegang hebben tot deze wijze van geschillenbeslechting. Nog los van het feit dat schuldeisers niet altijd toegang zullen hebben tot de procedure bij de $\mathrm{OK}$, is het ook om andere redenen interessant om te bekijken of de 'oude dame' een grotere rol zou kunnen krijgen in dit speelveld. Biedt bijvoorbeeld het arsenaal van de voorzieningenrechter voldoende mogelijkheden om een succesvolle debt for equity swap te bewerkstelligen? En zo ja, hoe zou een dergelijk vonnis van de voorzieningenrechter zich verhouden tot art. 1 EP EVRM en hoe verhoudt het zich qua procedurele waarborgen tot de enquêteprocedure?

\subsection{Arsenaal van de voorzieningenrechter}

Indien een schuldeiser besluit de gang naar de voorzieningenrechter te maken om daar een onmiddellijke voorziening te vragen teneinde een omzetting van schuld in aandelenkapitaal af te dwingen, kan de voorzieningenrechter - ervan uitgaande dat de vordering zo is ingestoken dat zij zich leent voor behandeling in kort geding ${ }^{26}$ - die eis dan honoreren?

In de eerste plaats zal de voorzieningenrechter de belangen van de partijen moeten afwegen. De gezichtspunten die door de OK zijn geformuleerd, kunnen mijns inziens op de volgende wijze worden toegepast bij het maken van deze belangenafweging. Zodra de voorzieningenrechter overtuigd is dat (1) de onderneming wordt geconfronteerd met een financieel probleem dat het voortbestaan daarvan bedreigt, (2) de organen van de vennootschap niet tot een gepaste oplossing kunnen komen en (3) de oplossing voor het financiële probleem dat de continuiteit van de onderneming bedreigt enkel gelegen kan zijn in het omzetten van schuld in nieuwe aandelen, zou een voorzieningenrechter een gevraagde voorziening kunnen treffen.

Wat betreft de concrete voorziening die de voorzieningenrechter kan treffen, zij opgemerkt dat hij zich feitelijk slechts aan twee wezenlijke beperkingen te houden heeft. In kort geding kan in beginsel namelijk geen declaratoir of constitutief

25. Ik bespreek hier niet de mogelijkheid van het vragen van een voorlopige voorziening in het kader van een aanhangige bodemprocedure, aangezien deze wijze van het verkrijgen van een voorziening in de regel meer tijd zal vergen vergeleken met de procedure in kort geding en dus niet aantrekkelijk zal zijn voor een snelle geschillenbeslechting in financiële noodsituaties, vgl. M. den Besten, Samenloop van voorlopige voorzieningen in het burgerlijk procesrecht, in: I.S.J. Houben e.a. (red.), Samenloop (BWKJ 23, Meijersreeks), Deventer: Kluwer 2007, p. 234-235.

26. Bijv. door nakoming van een opgesteld herstructureringsplan te eisen op straffe van een dwangsom, vgl. Rb. Amsterdam 20 december 2001, JOR 2002/26 (Gorillapark), waarin de voorzieningenrechter een dwarsliggende aandeelhouder dwong om zich te gedragen naar een overeenkomst waar hij geen partij bij wilde worden, om zodoende een emissie te bewerkstelligen. vonnis worden verkregen. ${ }^{27}$ Op deze twee beperking na kan de voorzieningenrechter - althans in theorie - vele voorzieningen treffen die een debt for equity swap mogelijk zouden maken. Zo kan de voorzieningenrechter, indien een voorstel voor een debt for equity swap al is voorbereid, de zittende aandeelhouders gebieden zich te gedragen naar het voorstel en daarbij tevens besluiten tot het opleggen van een dwangsom aan de aandeelhouders voor zover zij dat nalaten, om zodoende de medewerking aan de emissie te bewerkstelligen. ${ }^{28}$ Ook zou de voorzieningenrechter een andere voorziening kunnen treffen die hem gevraagd wordt, waarbij net als in het kader van de enquêteprocedure als uitgangspunt heeft te gelden dat het feit dat de gevraagde voorziening feitelijk onomkeerbare gevolgen zal hebben op zichzelf geen grond is om de voorziening ongeschikt te achten voor kort geding. ${ }^{29}$ Weliswaar moet de voorzieningenrechter bij het vormen van zijn oordeel acht slaan op eventueel restitutierisico, maar dat neemt niet weg dat hij op goede gronden bijvoorbeeld kan oordelen dat, vanwege het spoedeisende belang om de onderneming te redden, zijn vonnis in de plaats treedt van zowel het aandeelhoudersbesluit als de notariële akte tot uitgifte van aandelen aan de schuldeisers (al dan niet met uitsluiting van het voorkeursrecht uit art. 2:96a/206a BW). ${ }^{30}$

In ieder geval theoretisch zou een voorzieningenrechter in kort geding dus prima uit de voeten moeten kunnen bij het behandelen van een verzoek om een gedwongen omzetting van schuld in aandelen.

\subsection{Art. 1 EP EVRM en procedurele waarborgen}

Kijkend naar de eventuele inbreuk die een onmiddellijke voorziening in kort geding zou maken op het eigendomsrecht van de zittende aandeelhouders, moet wederom worden vastgesteld of die inbreuk is voorzien bij wet, het algemeen belang dient en proportioneel is. Ik meen dat wanneer de voorzieningenrechter de bovengenoemde criteria toepast bij het vormen van zijn oordeel en tevens voldoende gemotiveerd tot dat oordeel komt, al snel voldaan zal kunnen zijn aan de eisen van het dienen van het algemeen belang en proportionaliteit. Of de inbreuk op het eigendomsrecht echter voldoende voorzienbaar bij wet is, zoals het EHRM eist, valt moeilijker te voorspellen. De wettelijke basis van de voorzieningenrechter om een voorziening te treffen op grond van art. 254 van het Wet-

27. Deze uitgangspunten zijn niet absoluut, maar hebben wel als heersende leer te gelden in rechtspraak en literatuur. Zie bijv. HR 6 april 2012, NJ 2012/234. Zie voor een overzicht van literatuur en verwijzingen T.F.E. Tjong Tjin Tai, Burgerlijke rechtsvordering (losbl.), Deventer: Kluwer, aant. 3 bij art. $256 \mathrm{Rv}$

28. Vgl. De Kluiver 2006, p. 44-45.

29. Zie Tjong Tjin Tai, Burgerlijke rechtsvordering (losbl.), aant. 3 bij art. $256 \mathrm{Rv}$ en Van Schilfgaarde, noot bij Novero, nr. 17; vgl. voorts HR 8 februari 1946, NJ 1946/166 (Van den Heuvel/Van den Heuvel \& Co), HR 12 februari 1947, NJ 1947/157 m.nt. EMM (Bakker/Gem. Genemuiden) en HR 11 februari 1994, NJ 1994/651 m.nt. HJS (Van Kooten/Wilmink).

30. Vgl. HR 21 juni 2002, NJ 2002/420, waarbij de rechter in kort geding bepaalde dat zijn uitspraak niet alleen een soortgelijke machtiging als bedoeld in art. 3:174 lid $1 \mathrm{BW}$ meebracht, maar tevens op grond van art. 3:300 lid $2 \mathrm{BW}$ in de plaats trad van (een deel van) de akte. 
boek van Burgerlijke Rechtsvordering (Rv) is zeer ruim geformuleerd en daarom op zichzelf waarschijnlijk niet kwalificerend als een voldoende voorzienbare wettelijke basis. Daar staat tegenover dat art. $254 \mathrm{Rv}$ in samenhang met art. 255-259 $\mathrm{Rv}$ qua tekst lijkt te suggereren dat de voorzieningenrechter slechts tijdelijke, de hoofdzaak niet schadende uitspraken kan doen, terwijl uit de rechtspraak en de praktijk wel blijkt dat het oordeel in kort geding niet zelden definitief is en tot blijvende gevolgen kan leiden. Wat dat betreft blijkt dus uit de jurisprudentie en is derhalve voorzienbaar dat het oordeel van de voorzieningenrechter ingrijpender kan zijn dan de tekst van art. 254 e.v. $\mathrm{Rv}$ suggereert. Daarnaast is er al rechtspraak bekend waarbij de voorzieningenrechter een voorziening trof die tot een gedwongen aandelenemissie leidde. ${ }^{31}$ Deze aanknopingspunten zouden voldoende voorzienbare wettelijke basis in de zin van de rechtspraak van het EHRM kunnen vormen, waarbij nog zij aangetekend dat elke rechtsontwikkeling inherent een bepaald begin moet hebben en dus nooit in concrete zin volledig voorzienbaar kan zijn. ${ }^{32}$ Mits de voorzieningenrechter een duidelijke motivering geeft waarom hij overgaat tot het toekennen van de onmiddellijke voorzieningen, zou daarom een op die wijze gerealiseerde debt for equity swap niet per se in strijd met art. 1 EP EVRM hoeven te komen, maar dat is niet met zekerheid vast te stellen.

Waar de kritiek op de enquêteprocedure zich tevens richtte op het gebrek aan procedurele waarborgen, zijn deze waarborgen in de procedure in kort geding volop aanwezig. De kort geding procedure kent een eigen procesgang, waarbij hoger beroep en zelfs cassatie tegen de rechterlijke oordelen in kort geding openstaan. Daarnaast geldt dat uit art. $257 \mathrm{Rv}$ volgt dat de bodemrechter niet gebonden is aan de uitspraak in kort geding, waardoor ook in het kader van een eventueel aanhangige bodemprocedure er wederom twee feitelijke instanties en cassatie doorlopen kunnen worden. ${ }^{33} \mathrm{Nu}$ lijkt dit wellicht een goede, want met veel waarborgen omklede procesgang, maar voor een gedwongen debt for equity swap makt dit de voorzieningenrechter in veel gevallen feitelijk tot een ongeschikt forum. ${ }^{34}$ Voor een financier die besluit om de schuld die de onderneming aan hem heeft om te zetten in aandelenkapitaal, zal er veel aan gelegen zijn om te zorgen dat de onderneming gezond voort blijft bestaan. Daar hoort wellicht het aantrekken van nieuwe financiering bij, of het treffen van andere maatregelen die moeilijk terug te draaien zijn. Ervan uitgaande dat de schuldeisers de kansen van hoger beroep en cassatie in kort geding nog wel willen afwachten, kunnen zij nog steeds

31. Vgl. Rb. Amsterdam 20 december 2001, JOR 2002/26 (Gorillapark), welke uitspraak werd bekrachtigd in Hof Amsterdam 25 april 2002, JOR 2002/128.

32. Zie A. Doorman, JOR 2011/115 (Inter Access), nr. 22.

33. Tjong Tjin Tai, Burgerlijke rechtsvordering (losbl.), aant. 4 bij art. 257 Rv.

34. Vgl. R.M. Hermans, Heeft het kort geding nog een toekomst als zelfstandige procedure?, in: Bodem kort geding (Rullmann-bundel), Rechtbank Amsterdam 2013: 'Het voornaamste probleem in dit verband is dat de kortgedingrechter geen vonnis kan wijzen waarvan de rechtsgevolgen in een bodemprocedure niet meer kunnen worden teruggedraaid, terwijl partijen daarbij soms wel een spoedeisend belang hebben.' worden geconfronteerd met een bodemprocedure die potentieel jaren in beslag neemt. Daarbij heeft de rechter in de bodemprocedure de mogelijkheid om tot een oordeel te komen waarbij de transactie die is gebaseerd op de onmiddellijke voorziening volledig moet worden teruggedraaid. Indien de bodemprocedure op die wijze als een zwaard van Damokles boven het hoofd blijft hangen van de financiers van een onderneming, zal het geen aantrekkelijk perspectief zijn om langs deze weg een debt for equity swap te realiseren.

\section{Dwangakkoord buiten insolventie}

\subsection{Wetsvoorstel WCO II}

Hoewel het nog geen geldend recht betreft, verdient het voorontwerp voor de WCO II op deze plaats te worden besproken. De WCO II strekt ertoe een regeling in te voeren voor de totstandkoming van een dwangakkoord buiten faillissement en beoogt het proces van herstructurering van problematische schulden bij ondernemingen buiten faillissement te flexibiliseren en te bespoedigen. Het voordeel van een dwangakkoord buiten insolventie wordt geacht besloten te liggen in het feit dat door middel van het aanbieden en vaststellen van een dergelijk akkoord een onderneming financieel kan worden geherstructureerd, terwijl daarbij de meeste waarde voor alle betrokkenen behouden blijft. ${ }^{35} \mathrm{Bij}$ het opstellen van de regeling van het dwangakkoord buiten insolventie heeft de wetgever inspiratie opgedaan bij de in Engeland gebruikte scheme of arrangement en de in de Verenigde Staten gehanteerde Chapter 11procedure. $^{36}$

Een van de noviteiten die is verbonden aan de WCO II is dat het wetsvoorstel uitdrukkelijk voorziet in een gedwongen debt for equity swap buiten insolventie. ${ }^{37}$ Daarbij geldt dat het dwangakkoord zowel door de rechtspersoon/schuldenaar kan worden aangeboden als door diens aandeelhouders of schuldeisers (vergelijk conceptart. 368 van de Faillissementswet, Fw). Dit opent dus uitdrukkelijk de mogelijkheid voor een gedwongen debt for equity swap op instigatie van de schuldeisers van

35. Zie voor een roep om een dwangakkoord buiten insolventie: R.D. Vriesendorp, R.M. Hermans \& K.A.J. de Vries, Herijking faillissementsrecht en het informeel akkoord: gemiste kans of opportunity voor een Nederlandse scheme of arrangement?, TvI 2013/12, J.T. Jol, Wettelijk faciliteren van (financiële) herstructureringen: het dwangakkoord, in: J.T. Jol e.a., Herstructurering en insolventie: naar een scheme of arrangement? (ZIFO-reeks, deel 9), Deventer: Kluwer 2013, p. 37-53 en J.J. van Hees, Herstructurering met behulp van faillissement, in: G. van Solinge e.a. (red.), Herstructurering van ondernemingen in financiële moeilijkheden (Serie vanwege het Van der Heijden Instituut, deel 124), Deventer: Kluwer 2014 .

36. Concept-MvT, p. 12, raadpleegbaar op: <www.internetconsultatie.nl/ wco2>. Zie over dit wetsvoorstel o.m. R.D. Vriesendorp, Het buitengerechtelijk akkoord en het concept-wetsvoorstel WCO II, in: D. Busch e.a. (red.), Wet continuiteit ondernemingen (delen I en II) en het bestuursverbod (Preadvies van de Vereeniging 'Handelsrecht'), Zutphen: Uitgeverij Paris 2014, A.M. Mennens \& P.M. Veder, Clementie en recht: het dwangakkoord buiten insolventie, NTBR 2015/2 en M.L. Lennarts, De WCO II: solide basis voor herstructureringen of voer voor litigation? in: M. Holtzer e.a., Geschriften vanwege de Vereniging Corporate Litigation 2014-2015, Deventer: Wolters Kluwer 2015, p. 269-288.

37. Concept-MvT, p. 18. 
een onderneming. ${ }^{38}$ Hoe zou de totstandkoming van een dergelijk dwangakkoord in haar werk gaan?

\subsection{Totstandkoming van het dwangakkoord voor een debt for equity swap}

Zoals gezegd kunnen onder het regime van de WCO II de schuldeisers, of een aantal van hen, ter herstructurering van de schulden van een schuldenaar een akkoord aanbieden dat voorziet in een wijziging van hun rechten. Op grond van conceptart. 368 lid 2 Fw zal een schuldeiser de schuldenaar eerst een termijn moeten stellen om zelf een akkoord aan te bieden, indien de schuldeiser voorziet dat zijn schuldenaar met het betalen van zijn opeisbare schulden niet zal kunnen voortgaan. Gaat de schuldenaar op dat verzoek niet in, dan staat het de schuldeiser vrij om zelf het akkoord aan te bieden.

De inhoud van het voorgestelde akkoord staat grotendeels ter vrije dispositie van de schuldeiser, waarbij de randvoorwaarden waaraan het aangeboden akkoord moet voldoen grotendeels worden bepaald door hetgeen in conceptart. $370 \mathrm{Fw}$ is geregeld. Naast het exacte plan voor het doorvoeren van de financiële herstructurering, moet het voorgestelde akkoord tevens een indeling in klassen bevatten. $\mathrm{Nu}$ bepaalt conceptart. 369 lid $2 \mathrm{Fw}$ dat schuldeisers met vorderingen en aandeelhouders met rechten die redelijkerwijs als gelijkaardig moeten worden aangemerkt, in dezelfde klassen worden ondergebracht. Bij de invulling van de maatstaf of sprake is van 'rechten die redelijkerwijs als gelijkaardig moeten worden aangemerkt', moet volgens de concept-memorie van toelichting het volgende uitgangspunt worden gehanteerd:

'Als invulling van de thans voorgestelde maatstaf kan dienen dat een klasse moet omvatten de schuldeisers of aandeelhouders van wie de vorderingen of rechten zodanig met elkaar overeenkomen dat redelijkerwijs van hen mag worden verwacht dat zij in onderling overleg tot een gezamenlijk standpunt kunnen komen. Ter verdere inkleuring van deze maatstaf kan worden bezien of de rechten van degenen die door het akkoord worden gerakt zodanig overeenstemmen dat jegens hen van een enkel akkoord kan worden gesproken, indien dat het geval is moeten zij in een klasse worden ondergebracht. ${ }^{39}$

Het moge duidelijk zijn dat bij een aanwezige patstelling tussen schuldeisers en zittende aandeelhouders er niet kan worden verwacht dat zij in onderling overleg tot een gezamenlijk standpunt komen. Bij het indelen van klassen zal er dus ten minste een aparte klasse van schuldeisers en een aparte klasse van aandeelhouders moeten stemmen. Het akkoord zal, eventueel na inmenging van de rechter-commissaris, vervolgens ter stemming worden gebracht. Aangezien bij de stemming het dwangakkoord in beginsel alleen is aangenomen indien een

38. Praktisch gezien zal een schuldeiser voor het aanbieden van een akkoord wel de nodige informatie moeten hebben verzameld (vgl. conceptart. 370 Fw), zie ook Mennens \& Veder 2015, p. 10.

39. Concept-MvT, p. 54 meerderheid van de stemmen wordt behaald in alle betreffende klassen (conceptart. 372 lid 2 Fw), moet bij een tegenstemmende klasse van zittende aandeelhouders het akkoord als verworpen worden beschouwd. De hoop is op dat moment echter nog niet verloren voor een gedwongen debt for equity swap, aangezien de rechtbank op verzoek van de schuldeiser(s) kan overgaan tot het alsnog algemeen verbindend verklaren van het akkoord en zodoende een 'cross class cram down' kan bewerkstelligen. ${ }^{40}$

De cross class cram down is eigenlijk de enige manier waarop een gedwongen omzetting van schuld in aandelen kan worden bewerkstelligd indien de zittende aandeelhouders tegenstemmen. Zeker als bekend is dat de zittende aandeelhouders tegen gaan stemmen, stel ik me de eerste ronde van stemming in het kader van een door de schuldeisers voorbereide debt for equity swap voor als een pure formaliteit. Het akkoord zal worden verworpen en de schuldeisers dienen de rechtbank te vragen het akkoord alsnog algemeen verbindend te verklaren op grond van conceptart. 373 lid 2 Fw. De rechtbank zal dan moeten toetsen of de aandeelhouders in redelijkheid tot het getoonde stemgedrag hebben kunnen komen. Is dat niet het geval, dan kan zij besluiten tot het alsnog algemeen verbindend verklaren van het akkoord, tenzij de aandeelhouders daarbij een uitkering zouden ontvangen die lager is dan de uitkering die zij zouden ontvangen bij vereffening van de boedel van de schuldenaar in faillissement (conceptart. 373 lid 2 sub d FW). ${ }^{41}$ De rechtbank zal tevens de algemeen verbindend verklaring van het akkoord moeten weigeren als zich een van de imperatieve weigeringsgronden genoemd in conceptart. 373 lid $3 \mathrm{Fw}$ voordoet. Op basis van dit artikel weigert de rechtbank het verzoek tot algemeen verbindend verklaring indien de belangen van één of meer schuldeisers dan wel aandeelhouders door toewijzing van het verzoek onevenredig worden geschaad (sub a), de nakoming van het akkoord niet voldoende is gewaarborgd (sub b), het akkoord door bedrog, door begunstiging van één of meer schuldeisers of met behulp van andere oneerlijke middelen tot stand is gekomen dan wel berust op een kennelijk onjuiste voorstelling van zaken (sub c), of omdat andere zwaarwegende redenen zich naar het oordeel van de rechtbank tegen algemeen verbindend verklaring van het akkoord verzetten (sub d). Mijns inziens kan de rechtbank bij het vaststellen of de tegenstemmende aandeelhouders in redelijkheid tot het getoonde stemgedrag hebben kunnen komen direct deze imperatieve weigeringsgronden meenemen. ${ }^{42}$ Komt de rechtbank tot het oordeel dat, alle omstandigheden meenemend, de aandeelhouders niet hebben kunnen komen tot het getoonde stemgedrag, dan kan zij de algemeen

40. Zie hierover Mennens \& Veder 2015, p. 16 en Lennarts 2015, p. 283-286.

41. Juister zou overigens zijn om bij deze vermogensvergelijking aan te sluiten bij de huidige waarde van de onderneming going concern, zie hierover S.W. van den Berg, WCO II: de cram-down beschouwd vanuit waarderingsperspectief, FIP 2014/7 en Lennarts 2015, p. 284-285.

42. Vgl. Mennens \& Veder 2015, p. 17, die de kans klein achten dat een rechter eerst de cram down -beslissing van art. 373 lid 2 Fw neemt en vervolgens alsnog algemeenverbindendverklaring weigert. 
verbindend verklaring uitspreken, waarna de schuldeisers kunnen overgaan tot het effectueren van de aldus afgedwongen debt for equity swap.

\subsection{Art. 1 EP EVRM en procedurele waarborgen}

Indien het wetsvoorstel WCO II wordt gepromoveerd tot wet, dan kan er geen twijfel over bestaan dat deze wettelijke regeling een voldoende voorzienbare wettelijke basis biedt voor een inbreuk op een eigendomsrecht in de zin van art. 1 EP EVRM. Zeker in het kader van een gedwongen debt for equity swap maakt het voorontwerp voor de wettelijke regeling voldoende duidelijk dat, onder omstandigheden, een zittende aandeelhouder door middel van een algemeen verbindend verklaard dwangakkoord zijn positie kan zien verwateren of zelfs zal verliezen. De voorzienbaarheid bij wet is dus gegeven. De regeling van het dwangakkoord buiten faillissement is tevens zo ingestoken dat, mits juist toegepast door de betreffende rechtbank, er in het algemeen belang zal worden gehandeld en dat het ingrijpen tevens proportioneel is. ${ }^{43}$

Qua procedurele waarborgen heeft het wetsvoorstel een middenweg gekozen tussen de enquêteprocedure bij de OK en de procesgang in kort geding. De procedurele waarborgen waarin het wetsvoorstel voorziet, zijn aanmerkelijk groter dan die bij een enquêteprocedure, maar weer een stuk lichter (en daardoor praktischer) dan in kort geding het geval is. Zo bepaalt conceptart. $379 \mathrm{Fw}$ dat er hoger beroep openstaat tegen de afof toewijzing van de algemeen verbindend verklaring van het akkoord en kan op grond van conceptart. 380 Fw zelfs cassatie worden ingesteld. De termijnen waarbinnen hoger beroep en cassatie kunnen worden ingesteld, zijn steeds kort, te weten binnen acht dagen na de beschikking van de rechtbank, respectievelijk het gerechtshof. Op die wijze waarborgt de wetgever mijns inziens dat het dwangakkoord succesvol kan worden gebruikt binnen een financiële herstructurering die moet plaatsvinden onder hoge tijdsdruk, zonder dat het verwijt kan worden gemaakt dat er slechts één feitelijke instantie naar het vraagstuk heeft gekeken.

\section{Conclusie}

Naar geldend Nederlands recht zijn er mogelijkheden om buiten insolventie een gedwongen debt for equity swap te realiseren, maar met het oog op de toekomst zijn er zeker verbeteringen mogelijk. De enquêteprocedure bij de OK biedt naar geldend recht de beste mogelijkheid voor schuldeisers om zittende aandeelhouders te dwingen tot een omzetting van schuld in aandelen. Hoewel de (zuivere) casus die in deze bijdrage centraal staat tot op heden nog niet aan de orde is geweest bij de OK, zal - gelet op de proactieve houding van de OK en de belangen die op het spel kunnen staan - de enquêteprocedure mijns inziens het juiste forum kunnen zijn om een gedwongen debt for equity swap te bewerkstelligen. Het pijnpunt voor de toepasselijkheid van de enquêteprocedure zit echter in de toegankelijkheid van deze procedure voor schuldeisers. Zonder medewerking van het bestuur of eigen toegang op basis van contract of statuten zal een schuldeiser zich niet tot de OK kunnen wenden om een gedwongen omzetting van schuld in aandelen te bewerkstelligen.

De procedure bij de voorzieningenrechter biedt in theorie weliswaar de mogelijkheid om een debt for equity swap te bewerkstelligen, maar stuit niettemin op een aantal bezwaren. Het eerste bezwaar ziet op het feit dat art. $254 \mathrm{Rv}$ en de daaraan verbonden rechtspraak mogelijk niet voldoende voorzienbare wettelijke basis bieden om een inbreuk op het eigendomsrecht in de zin van art. 1 EP EVRM te rechtvaardigen. Maar ook al neemt men deze horde, dan nog heeft de procedure in kort geding het praktische probleem dat de onmiddellijke voorziening de uitkomst in een bodemprocedure niet kan prejudicieren, terwijl ze zelf ook nog openstaat voor hoger beroep. De definitieve oplossing waar de financieel penibele situatie om vraagt, is dan dus simpelweg niet te krijgen in kort geding.

Het wetsvoorstel WCO II kent verschillende sterken punten wanneer men er vanuit het perspectief van het bewerkstelligen van een gedwongen debt for equity swap naar kijkt. Een van de sterke punten van het wetsvoorstel is dat het een uitdrukkelijke wettelijke basis geeft waaruit voldoende voorzienbaar een inbreuk op het eigendomsrecht van de aandeelhouder in de zin van art. 1 EP EVRM kan voortvloeien om een gerechtvaardigde inbreuk te zijn. Daarnaast zal een schuldeiser eerder toegang hebben tot deze procedure dan tot een enquêteprocedure bij de OK. Ten slotte valt te prijzen dat de wetgever weliswaar procedurele waarborgen heeft geboden aan alle partijen, maar dit heeft gedaan zonder daarbij de noodzakelijke snelheid en efficiëntie weg te nemen. Het wetsvoorstel WCO II moet op bepaalde punten nog verder worden uitgewerkt en aangepast, bijvoorbeeld als het gaat om de exacte waardering van de belangen die toekomen aan de zittende aandeelhouder. Dergelijke aanpassingen zijn overigens gebruikelijk bij een wetsvoorstel dat ter consultatie is neergelegd. Dit neemt echter niet weg dat het wetsvoorstel WCO II nu al een goed geraamte geeft voor een gedwongen debt for equity swap buiten insolventie. Indien het wetsvoorstel tot wet promoveert, zou het dus een waardevolle aanvulling kunnen opleveren voor het Nederlandse vermogens- en insolventierecht op dit vlak.

43. Zie tevens concept-MvT, p. 66-67. 